
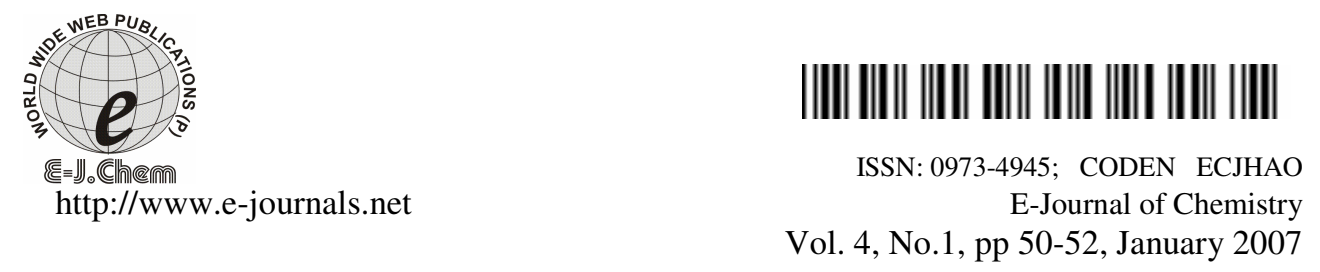

\title{
Spectrophotometric Determination of Famciclovir and Racecodotril Using 2, 6-Dichloroquinone-Chlorimide
}

\author{
M.VAMSI KRISHNA, P.V.MADHAVI LATHA and D. GOWRI SANKAR
}

Department of Pharmaceutical Sciences, Andhra University, Visakhapatnam - 530003. marothu_vamsi@rediffmail.com

Received 2 August 2006; Accepted 8 September 2006

\begin{abstract}
A simple, sensitive spectrophotometric method for the determination of Famciclovir and Racecodotril is developed. It is based on the formation of a colored oxidative coupling product between 2,6dichloroquinone-chlorimide and the drug is described. The method has been extended to pharmaceutical preparations. The absorption maxima and Beer's law limits for Famciclovir are $500 \mathrm{~nm}, 20-100 \mu \mathrm{g} / \mathrm{ml}$ and for Racecodotril are $460 \mathrm{~nm}, 12.5-62.5 \mu \mathrm{g} / \mathrm{ml}$.
\end{abstract}

Keywords: Spectrophotometric, Famciclovir, Racecodotril and 2,6dichloroquinone chlorimide.

\section{Introduction}

Famciclovir $(\mathrm{FCV})^{1-2}$ is an anti viral drug and is chemically 1,3 - propanediol , 2 - [ 2 -(2 amino - 9H - purin - 9 -yl)ethyl] - , diacetate (ester). Racecodotril (RCD) is an antidiarrhoeal drug and chemically it is glycine , $\mathrm{N}-[2-$ [(acetyl thio)methyl] 1 - oxo-3-phenyl propyl ] - phenyl methyl ester Literature survey reveals that no visible methods are reported for the estimation of FCV and a HPLC method is reported for $\mathrm{RCD}^{3}$.The present investigation has been undertaken to develop simple, accurate and reliable spectrophotometric method for the estimation of FCV and RCD in pure as well as in pharmaceutical dosage forms. 


\section{Experimental}

\section{Instrumentation}

Spectral and absorbance measurements were made on Systronics UV-Visible spectrophotometer- 117 with $10 \mathrm{~mm}$ matched quartz cells.

\section{Chemicals and reagents}

All the chemicals used were of analytical grade. Famciclovir and Racecodotril were gift samples from Cipla Labs,Bombay, India and Dr.Reddy's Laboratories, Hyderabad, India.Tablets of Famciclovir[FAMTREX- $250 \mathrm{mg}$ (Cipla)] and capsules of Racecodotril[REDOTIL-100mg (Dr.Reddy's)] were purchased from local market. 2,6dichloroquinone-chlorimide(0.4\%):400 $\mathrm{mg}$ of 2,6-dichloroquinone-chlorimide was dissolved in $100 \mathrm{ml}$ of isopropanol.

\section{Preparation of standard solutions}

Accurately weighed $100 \mathrm{mg}$ of FCV or RCD was dissolved in $100 \mathrm{ml}$ of distilled water or methanol and the solutions were diluted with distilled water or methanol to obtain a final concentration of $400 \mu \mathrm{g} / \mathrm{ml}$ for FCV of $250 \mu \mathrm{g} / \mathrm{ml}$ for RCD.

\section{Preparation of sample solutions}

An accurately weighed amount of tablet powder of FCV equivalent to $100 \mathrm{mg}$ was dissolved in $100 \mathrm{ml}$ of distilled water and filtered. This solution was further diluted with distilled water so as to obtain a concentration of $400 \mu \mathrm{g} / \mathrm{ml}$. Accurately weighed amount of capsule powder of RCD equivalent to $100 \mathrm{mg}$ was dissolved in $100 \mathrm{ml}$ of methanol and filtered. This solution was further diluted with methanol so as to obtain a concentration of $250 \mu \mathrm{g} / \mathrm{ml}$.

\section{Assay procedure}

Aliquots of solution 0.5 to $2.5 \mathrm{ml}(400 \mu \mathrm{g} / \mathrm{ml}$ for $\mathrm{FCV}$ or $250 \mu \mathrm{g} / \mathrm{ml}$ for RCD) were transferred into a series of $10 \mathrm{ml}$ graduated tubes, $1.0 \mathrm{ml}$ of DCQC for FCV or $1.5 \mathrm{ml}$ of DCQC for RCD was added to each tube and heated on boiling water bath for $20 \mathrm{~min}$, cooled and made up to the volume with distilled water. The absorbance was measured at $500 \mathrm{~nm}$ for FCV or $460 \mathrm{~nm}$ for RCD against a reagent blank. The amount of FCV and RCD present in the sample solution was computed from its calibration curve.

\section{Results and Discussion}

The optical characteristics such as Beer's law limits, molar absorptivity, Sandell's sensitivity are presented in Table-1.The regression analysis was made for the slope (a), intercept (b) and correlation coefficient ( $r$ ) and the results are summarized in Table-1.The percent relative standard deviation and percent range of error ( 0.05 and 0.01 confidence limits) are given in Table-1. The results showed that the method have reasonable precision.

The accuracy of the method was ascertained by comparing the results obtained with the proposed and reference methods ${ }^{\mathrm{R}}$ in the case of formulations and are presented in Table2.As an additional check of accuracy of the method, recovery experiments were performed by adding known amounts of pure drug to pre-analysed formulations and percentage recovery values obtained are given in Table-2.Recovery experiments indicated the absence of interferences from the commonly encountered pharmaceutical additives and excepients.

Thus the proposed method is simple and selective with reasonable precision and accuracy and can be employed for the routine determination of FCV and RCD in quality control analysis. 
Table 1. Optical characteristics and precision of the proposed methods

\begin{tabular}{lcc}
\hline \multicolumn{1}{c}{ Parameters } & FCV & RCD \\
\hline$\lambda_{\max }(\mathrm{nm})$ & 500 & 460 \\
Beer's law limit $(\mu \mathrm{g} / \mathrm{ml})$ & $20-100$ & $12.5-62.5$ \\
Molar absorptivity $\left(1 \mathrm{~mole}^{-1} \mathrm{~cm}^{-1}\right)$ & $2.57 \times 10^{3}$ & $4.31 \times 10^{3}$ \\
Sandell's sensitivity & 0.125 & 0.0892 \\
$\left(\mu \mathrm{g} \mathrm{cm}^{-2} / 0.001\right.$ absorbance unit) & & \\
Regression equation $(\mathrm{Y}=\mathrm{a}+\mathrm{bC})$ & 0.0081 & 0.0112 \\
Slope $(\mathrm{b})$ & 0.00124 & 0.00376 \\
Intercept $(\mathrm{a})$ & 0.9999 & 0.9997 \\
Correlation coefficient $(\mathrm{r})$ & 0.369 & 0.541 \\
Relative standard deviation $(\%) *$ & & \\
\%Range of error $($ Confidence limits)* & 0.308 & 0.452 \\
0.05 level & 0.456 & 0.669 \\
0.01 level & & \\
\hline
\end{tabular}

*Average of eight determinations

In $\mathrm{Y}=\mathrm{a}+\mathrm{bC}, \mathrm{Y}$ is absorbance and $\mathrm{C}$ is concentration

Table 2 Assay and recovery of FCV and RCD in dosage forms

\begin{tabular}{|c|c|c|c|c|}
\hline \multirow{2}{*}{$\begin{array}{l}\text { Name of the } \\
\text { dosage form }\end{array}$} & \multirow{2}{*}{$\begin{array}{l}\text { Labeled } \\
\text { amount } \\
(\mathrm{mg})\end{array}$} & \multicolumn{2}{|c|}{ Content of drug found (mg) } & \multirow{2}{*}{$\begin{array}{l}\text { \%Recovery by } \\
\text { proposed method }^{* *}\end{array}$} \\
\hline & & Proposed method & Reported method $^{4}$ & \\
\hline \multicolumn{5}{|l|}{ Famciclovir } \\
\hline$\overline{\text { Tablets I }}$ & 250 & 249.88 & 250.22 & 99.95 \\
\hline $\begin{array}{l}\text { Tablets II } \\
\text { Racecodotril }\end{array}$ & 250 & 249.90 & 250.06 & 99.96 \\
\hline$\overline{\text { Capsules I }}$ & 100 & 99.99 & 100.03 & 99.99 \\
\hline Capsules II & 100 & 99.89 & 99.98 & 99.89 \\
\hline
\end{tabular}

The authors are thankful to Cipla labs and Dr.Reddys Laboratories for providing the gift sample of Famciclovir and Racecodotril and also to the Dept. of Pharmaceutical sciences, Andhra University for providing the laboratory facilities.

\section{References}

1. Diaz-Mitoma F, Sibbald R G, Shafran S D, Boon R and Saltzman R L. J.Am. Med.Assoc. 1998, 280, 887.

2. Vere Hodge R A. Antiviral Chem. Chemother. 1993, 4, 67.

3. Zhao, Zhu and Liu. Zhongguo Yaoxue Zazhi. 2001, 36, 267.

4. Gowri Sankar D, Pawar A K M, Kalyan Sumanth S and Madhavi Latha P V. Asian J.Chem. 2005, 17, 2043. 


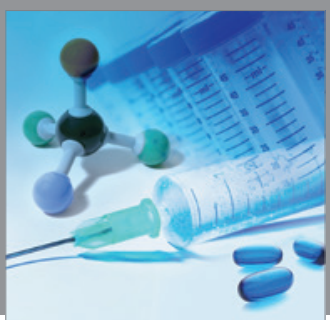

International Journal of

Medicinal Chemistry

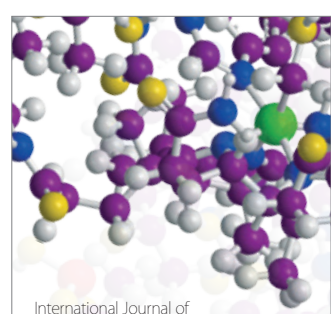

Carbohydrate Chemistry

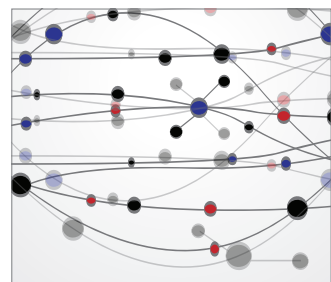

The Scientific World Journal
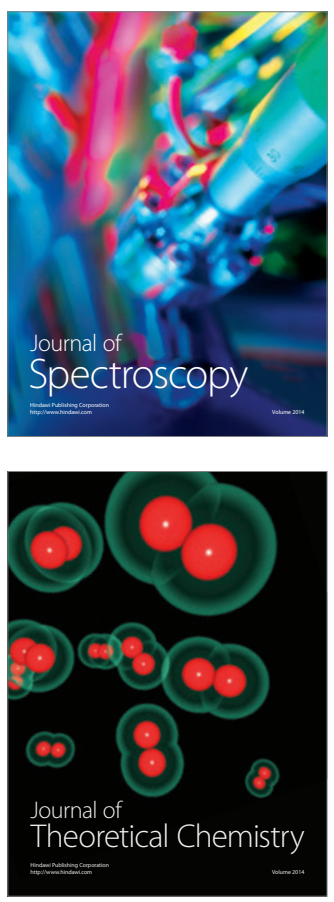
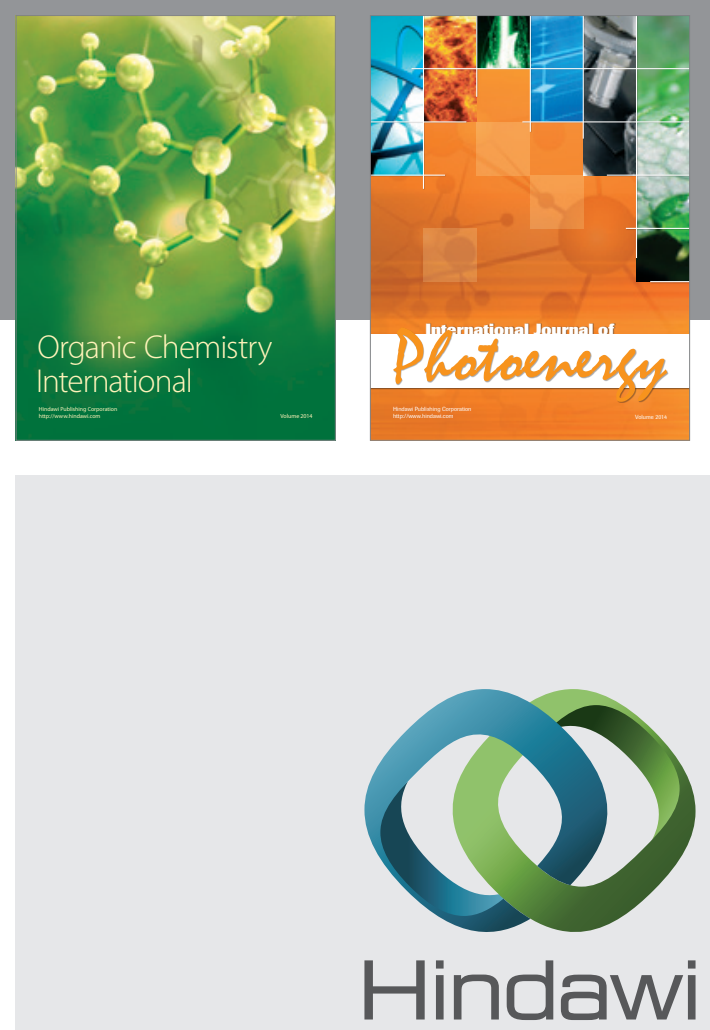

Submit your manuscripts at

http://www.hindawi.com
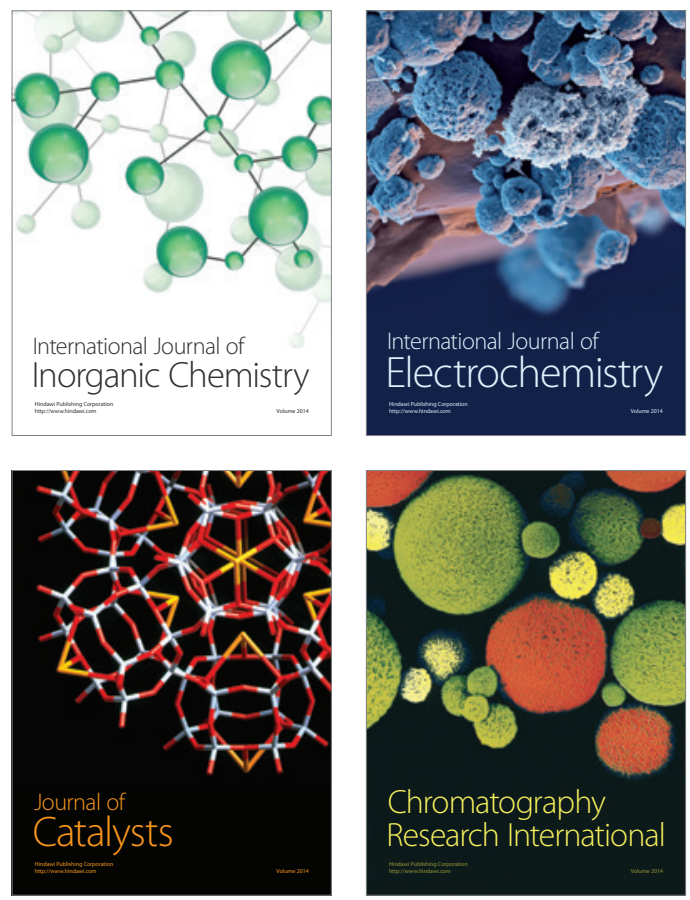
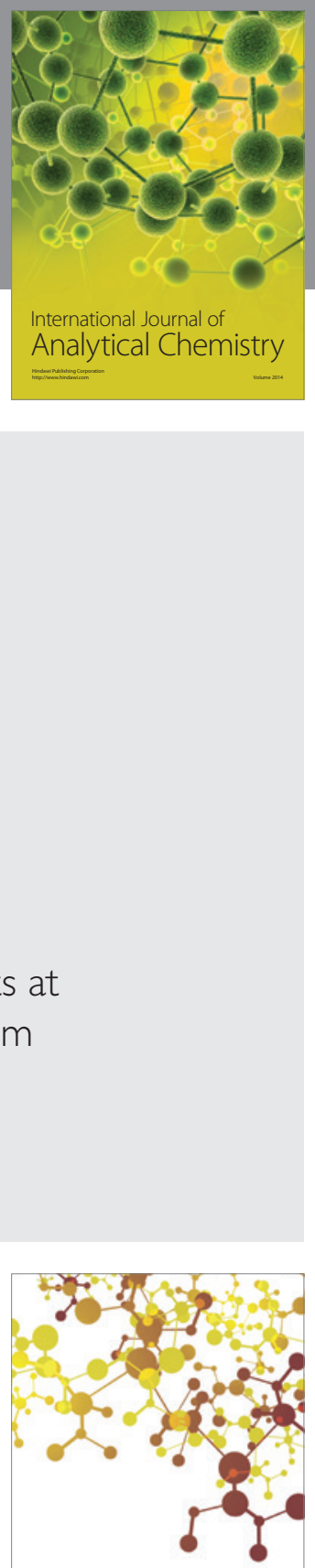

Journal of

Applied Chemistry
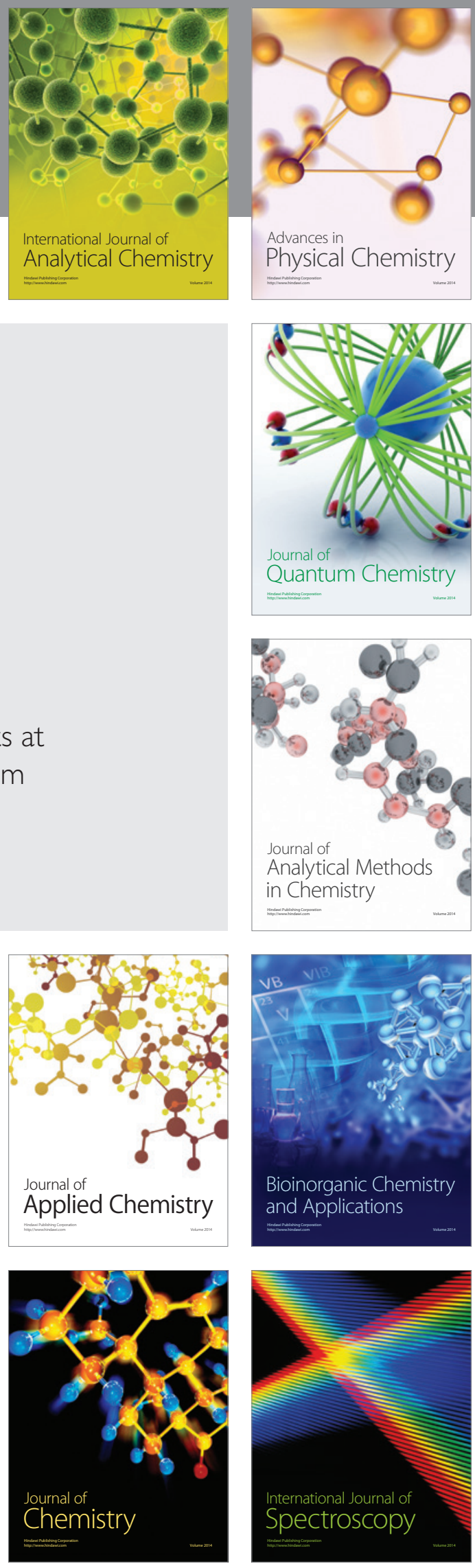